\title{
Diversity of small land mammals in a subtropical Atlantic forest in the western region of the state of Santa Catarina, southern Brazil
}

\author{
Renan Maestri $^{1,2,4}{ }^{\text {, Daniel Galiano }}{ }^{3}$, Bruno Busnello Kubiak ${ }^{3}$ \& Jorge Reppold Marinho ${ }^{1}$ \\ ${ }^{1}$ Programa de Pós-Graduação em Ecologia, Universidade Regional Integrada do Alto Uruguai e das \\ Missões, Erechim, RS, Brazil. \\ ${ }^{2}$ Programa de Pós-Graduação em Ecologia, Universidade Federal do Rio Grande do Sul, Porto Alegre, \\ RS, Brazil. \\ ${ }^{3}$ Programa de Pós-Graduação em Biologia Animal, Universidade Federal do Rio Grande do Sul, \\ Porto Alegre, RS, Brazil. \\ ${ }^{4}$ Corresponding author: Renan Maestri, e-mail: renanmaestri@gmail.com
}

MAESTRI, R., GALIANO, D., KUBIAK, B.B., MARINHO, J.R. Diversity of small land mammals in a subtropical Atlantic forest in the western region of the state of Santa Catarina, southern Brazil. Biota Neotropica. 14(4): e20140129. http://dx.doi.org/10.1590/1676-06032014012914

\begin{abstract}
Small land mammals possess features that significantly influence the dynamics of ecosystems and participate in various levels of the food web. In the Brazilian Atlantic Forest the richness of these animals is high, which makes them even more ecologically and numerically relevant in this environment. In this context, we investigated the species composition of small mammals in an unexplored area of southern Brazil, and compared the species composition of this area with other Atlantic Forest regions in order to understand how this community is related to others. The study area was located in an interior Atlantic forest formation, at a transition region between deciduous and Araucaria forests. Small mammals were captured at five collection points using pitfall traps. We compared the species composition found in our studied area with the composition of other 11 studies in different regions by a cluster analysis, and we investigated the presence of spatial autocorrelation between communities with a Mantel test. We recorded 779 individuals from 21 species of small rodents (15 species) and marsupials (six species) during the 13 months of the collection period. This richness was high compared to other studies conducted in the Atlantic Forest formations near to coastline and in interior forest formations. This may be a result of the conditions provided by this transition area (deciduous and Araucaria forests), where could be found elements of the both forests formations, which probably allows the establishment of small mammal species from both forest types. Despite differences in sampling effort of the studies, our results suggest that the interior forest formations may harbor a number of species comparable to the formations near the coast. The species composition of this area was similar to those found in other interior forest formations with the same phytophysiognomy characteristics and at nearby regions, and it was less similar to the distant formations located in southeastern and northeastern Brazil and nearby to the coastline. This can be a result of both the spatial autocorrelation (i.e. more nearby communities tend to have more similar species composition) and the differences of forest characteristics among regions.
\end{abstract}

Keywords: Richness, species composition, Uruguay River, Rodentia, Didelphimorphia.

MAESTRI, R., GALIANO, D., KUBIAK, B.B., MARINHO, J.R. Diversidade de pequenos mamíferos terrestres em floresta Atlântica subtropical na região oeste do estado de Santa Catarina, sul do Brasil. Biota Neotropica. 14(4): e20140129. http://dx.doi.org/10.1590/1676-06032014012914

Resumo: Pequenos mamíferos terrestres possuem características que influenciam significativamente a dinâmica dos ecossistemas, participando em vários níveis da teia trófica. Na floresta Atlântica brasileira a riqueza desses animais é alta, o que os torna ainda mais ecológica e numericamente relevantes neste ambiente. Neste contexto, nós investigamos a composição de espécies de pequenos mamíferos em uma área não estudada, e comparamos a composição de espécies desta área com outras regiões de floresta Atlântica de modo a entender como esta comunidade de pequenos mamíferos é relacionada a outras. A área de estudo está localizada em uma formação de floresta Atlântica de interior, em uma transição entre floresta decidual e floresta com Araucária. Os pequenos mamíferos foram capturados em cinco pontos de coleta por meio do método de armadilhas de interceptação e queda. Nós comparamos a composição de espécies encontrada em nosso estudo com a de outros 11 estudos realizados em diferentes regiões através de uma análise de agrupamento, e nós investigamos a presença de autocorrelação espacial entre comunidades por meio de um teste de Mantel. Nós registramos 779 indivíduos de 21 espécies de pequenos roedores (15 espécies) e 
marsupiais (seis espécies) durante um período de 13 meses de coleta. A riqueza é alta comparada com outros estudos em formações de floresta Atlântica próximas do litoral e formações de interior. Isso pode ser o resultado das condições fornecidas por esta área de transição (floresta decidual e floresta com Araucária), onde podem ser encontrados elementos das duas formações florestais, o que provavelmente permite o estabelecimento de espécies de pequenos mamíferos dos dois tipos de floresta. Apesar das diferenças no esforço amostral entre os estudos, esses resultados são uma boa indicação de que as formações de floresta Atlântica de interior podem abrigar um número de espécies comparáveis a de formações próximas da costa. A composição de espécies desta área é mais similar a de outras formações Atlânticas de interior com as mesmas características florestais e de regiões espacialmente próximas, e é menos similar as formações localizadas no sudeste e no nordeste do Brasil, e de regiões próximas da costa. Isso pode ser o resultado de autocorrelação espacial (i.e. comunidades mais próximas tendem a ter uma composição de espécies mais similar) e das diferenças nas características florestais entre as regiões.

Palavras-chave: Riqueza, composição de espécies, Rio Uruguai, Rodentia, Didelphimorphia.

\section{Introduction}

Small terrestrial mammals (both rodents and marsupials), characterized here as those that weigh less than $1 \mathrm{~kg}$ in average (Fonseca et al. 1996), are important numerically and possess features that significantly influence the dynamics of ecosystems (Pardini \& Umetsu 2006). They are important predators of insects, consume fruits, disperse seeds (Carvalho et al. 1999) and fungal spores (Pyare \& Longland 2001) as well as participate in the cycle of various zoonoses that affect man (Bonecker et al. 2009, Pinto et al. 2009). In addition to knowing the species composition of any community, it is important to understand how these species are distributed in space in comparison to other communities of different regions. Such information can assist us when devising of strategies for the conservation of the sampled sites and increasing our understanding of the ecological relationships between species (Begon et al. 2007).

The Atlantic Forest is one of the richest and most threatened biomes in the world. Efforts to understand and outline strategies to conserve biodiversity must be urgent (Myers et al. 2000). The richness of small land mammals, as with most animal groups, is remarkable in this region (Galindo-Leal \& Câmara 2003). There are approximately 100 species of small marsupials and rodents spread throughout the biome (Bonvicino et al. 2002, Pardini \& Umetsu 2006, Pinto et al. 2009, Paglia et al. 2012). Despite the increasing number of studies in this biome, some regions remain poorly sampled. For example, only a few studies of small mammal species have been carried out in the western state of Santa Catarina, where this study was conducted. In this region, the information available is results from fauna surveys (Studies of Environmental Impact) at hydroelectric plants (Cherem et al. 2008, Cherem et al. 2012).

In this context, the aims of our study was (1) to evaluate the species composition of small mammals present in a poorly sampled region in a transition between deciduous and Araucaria forests in southern Brazil; and (2) to compare the species composition of this area with other Atlantic Forest regions in order to understand how this community of small mammals is related to others. Additionally, we discuss the conservation potential of our study area based on the small mammal richness in relation to other studies.

\section{Material and Methods}

\section{Study area}

The study was conducted in a fragment of Atlantic Forest in a transition region between deciduous and Araucaria forests.
The fragment is located in the western region of the state of Santa Catarina in southern Brazil (Figure 1). The ground has a large slope; the altitude ranges from 388 to 600 meters above sea level. The total area of this fragment reaches approximately 400 hectares. About 300 hectares are of native vegetation, permeated by 100 hectares of a eucalyptus plantation. The surrounding area of the fragment is dominated by eucalyptus monocultures, forestry and housing. The area inside the

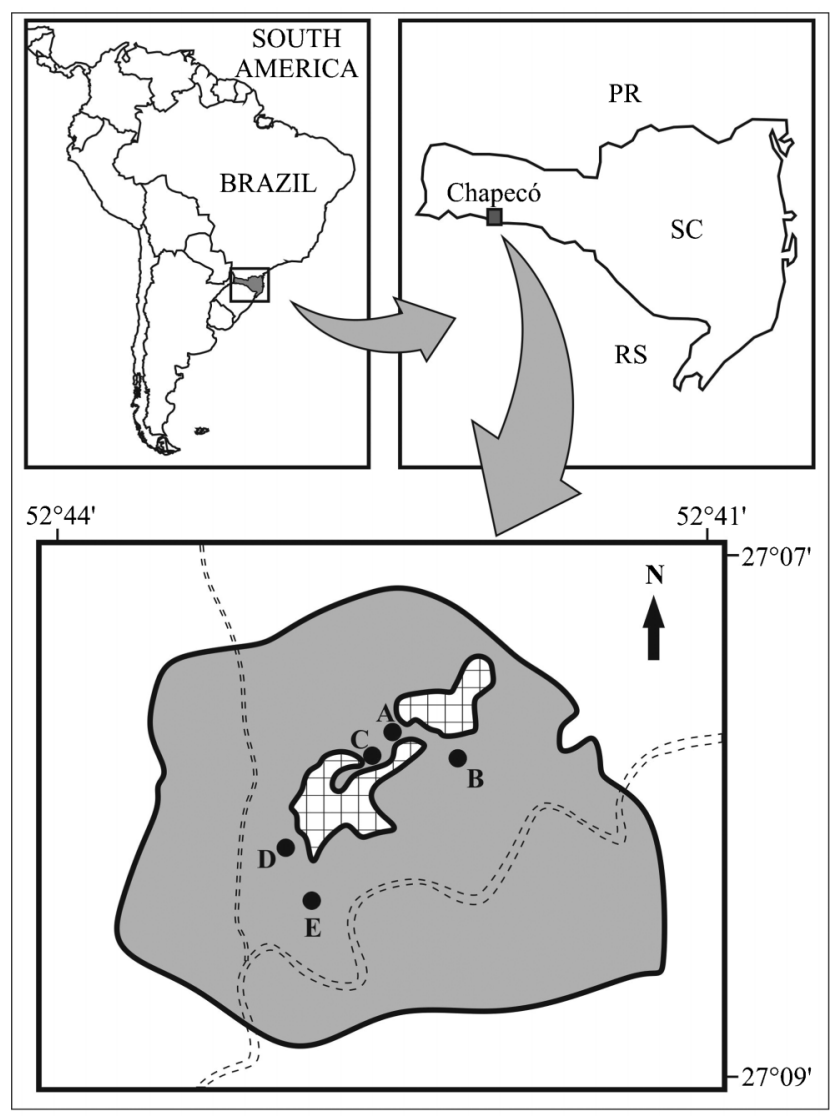

Figure 1. Sketch of the study area and its location in the context of the state of Santa Catarina and Brazil. The black dots represent the places where the traps to catch small mammals were located. The grey area represents the native vegetation (i.e. the transition between deciduous and Araucaria forest). The area in squares represents eucalyptus plantations. Dashed lines denote rivers; the vertical one is an unnamed river; and the horizontal one is the Passo dos Índios River. Acronyms: PR, Paraná state; SC, Santa Catarina state; RS, Rio Grande do Sul state. 
fragment was greatly affected by logging (approximately 10 years before our sample). The native forest is in regeneration, but moderate disturbances caused mainly by hunting has continued. The climate classified as Köeppen type $\mathrm{Cfb}$, mesothermic humid, with an average annual temperature of approximately $18^{\circ}$ to $19^{\circ} \mathrm{C}$ and an average annual rainfall of approximately $1,800 \mathrm{~mm}$ (Peel et al. 2007). Rainfall is equally distributed over the year. A warm season and a cold season are present, which gives the seasonal character of the forest. The subtropical climate favors the onset of the following two main types of vegetation: the deciduous forest commonly associated with the valley and the rivers, and the Araucaria forest occurring in higher places. The studied area was located at a transition region between these two physiognomies (Silva-Filho \& Pugues 2008). The Deciduous forest owes its name to foliar seasonality of the dominant arboreal elements, whose percentage of leaf fall is $50 \%$ or more in the colder months. Currently, the original vegetation has been reduced to a few fragments, usually located in steep terrain (Silva-Filho \& Pugues 2008). The Araucaria forest, typical in areas with high rainfall, presents a mixture of floras from different regions. One of its most remarkable features is the presence of Araucaria pine (Araucaria angustifolia (Bert.) O. Ktze.) (Netto et al. 2012). In the studied area, near the Chapecó River, the original forest was composed mainly of deciduous forest elements (e.g. Apuleia leiocarpa (Vogel) J.F.Macbr; Parapiptadenia rigida (Benth) Brenan; Cedrela fissilis Vell.), with the presence of some typical examples of Araucaria forest (e.g. Araucaria angustifolia; Ocotea porosa (Ness) Baroso; Luehea divaricata Mart. et. Zucc.) (Silva-Filho \& Pugues 2008, Netto et al. 2012).

\section{Data collection}

Small mammals were captured using only pitfall traps (see Ribeiro-Júnior et al. 2011 and Cechin \& Martins 2000 for discussion concerning this choice). These traps were distributed at five sampling points (A to E) (Figure 1). The maximum distance between the external points (A-E) was 1,180 meters; the inside points (A-B, A-C, B-C, C-D, D-E) were nearly $400 \mathrm{~m}$ apart. Each sample point consisted of 10 buckets with 100-liter capacities that were buried in the ground and arranged in a Y-shape. The distance between the buckets was 10 meters. A drift fence (plastic screen), with approximately $50 \mathrm{~cm}$ high, placed over the middle of each bucket, connected one bucket to another. The traps were left open for 10 consecutive days over the following 13 months: August 2011 (pilot field) and from October 2011 to September 2012. The overall sampling effort was 6,500 trap-nights. The sample points were revised daily during the sample period.

All of the individuals captured were collected for the preparation of their skin and skull and are deposited in the collection of the Museu Regional do Alto Uruguai (MURAU) of the Universidade Regional Integrada do Alto Uruguai e das Missões (URI) with the numbers MURAU301 to MURAU1061. This collection excluded specimens of the genus Didelphis Linnaeus 1758, and one individual of Guerlinguetus sp. that was visualized and did not fall in the pitfall. The animals were captured with the consent of environmental agencies (ICMBio), under the permanent and personal license number 15224-2 (J.R.M.).

\section{Data Analysis}

The richness, relative abundance and frequency of occurrence of the species in this study were quantified in totality (i.e. a sum of all the five sampling points). In the case of the genus Didelphis, individuals caught for a second time in less than two days at the same sample point were not considered in the abundance calculation for suspected of being the same individual. We choose this criterion as a method to estimate the abundance of Didelphis, because the individuals were not marked. A species accumulation curve was generated with 1,000 randomizations in the order of the samples.

We compared the species composition found in our studied area to the composition of other regions present in the Atlantic Forest biome (Table 1). All of the analyzed studies had survey durations greater than eight months. To do this comparison, a cluster analysis was carried out using the Jaccard coefficient of similarity and a UPGMA algorithm of clustering. To avoid bias, we did not consider in the analysis individuals classified at the taxonomic level of genus or exotic species. We analyzed the consistency of the similarity by a bootstrap analysis with 1,000 permutations, which gives a value (ranging from 0 to 100) stating the percentage of replicates where each node is

Table 1. List from the 13 small mammal surveys used to compose the cluster analysis. The number of species shown does not include those classified at the taxonomic level of genus or exotic species, this is the reason for some studies (including this one) show here fewer species. Acronyms: BA, Bahia state; ES, Espírito Santo state; RJ, Rio de Janeiro state; SP, São Paulo state; SC, Santa Catarina state; RS, Rio Grande do Sul state. Formation: CAF: Coastal Atlantic Forest (maximum of $80 \mathrm{~km}$ of the coast); IAF: Interior Atlantic Forest (minimum of $180 \mathrm{~km}$ from the coast).

\begin{tabular}{lcccc}
\hline Locality & Formation & Geographic coordinates & Number of species & Reference \\
\hline Una (BA) & CAF & $39^{\circ} 11^{\prime} \mathrm{W} ; 15^{\circ} 12^{\prime} \mathrm{S}$ & 15 & Pardini 2004 \\
Viana (ES) & $\mathrm{CAF}$ & $40^{\circ} 29^{\prime} \mathrm{W} ; 20^{\circ} 23^{\prime} \mathrm{S}$ & 19 & Pinto et al. 2009 \\
Itatiaia (RJ) & $\mathrm{CAF}$ & $44^{\circ} 34^{\prime} \mathrm{W} ; 22^{\circ} 29^{\prime} \mathrm{S}$ & 29 & Geise et al. 2004 \\
Cotia (SP) & $\mathrm{CAF}$ & $46^{\circ} 55^{\prime} \mathrm{W} ; 26^{\circ} 36^{\prime} \mathrm{S}$ & 21 & Pardini \& Umetsu 2006 \\
Florianópolis (SC) & $\mathrm{CAF}$ & $48^{\circ} 31^{\prime} \mathrm{W} ; 27^{\circ} 43^{\prime} \mathrm{S}$ & 10 & Graipel et al. 2006 \\
Cambará do Sul (RS) & $\mathrm{CAF}$ & $50^{\circ} 06^{\prime} \mathrm{W} ; 28^{\circ} 58^{\prime} \mathrm{S}$ & 6 & Dalmagro \& Vieira 2005 \\
Três Barras (SC) & IAF & $50^{\circ} 18^{\prime} \mathrm{W} ; 26^{\circ} 07^{\prime} \mathrm{S}$ & 8 & Cherem \& Perez 1996 \\
São Domingos (SC) & IAF & $53^{\circ} 33^{\prime} \mathrm{W} ; 26^{\circ} 40^{\prime} \mathrm{S}$ & 11 & Cherem et al. 2008 \\
Xanxerê (SC) & IAF & $52^{\circ} 24^{\prime} \mathrm{W} ; 26^{\circ} 36^{\prime} \mathrm{S}$ & 15 & Cherem et al. 2012 \\
Mato Castelhano (RS) & IAF & $52^{\circ} 11^{\prime} \mathrm{W} ; 28^{\circ} 17^{\prime} \mathrm{S}$ & 10 & Galiano et al. 2013; Galiano 2010 \\
Erechim (RS) & IAF & $52^{\circ} 16^{\prime} \mathrm{W} ; 27^{\circ} 38^{\prime} \mathrm{S}$ & 9 & Kessel 2011; Kubiak 2010; \\
Chapecó (SC) & & & 19 & Kubiak et al. 2009 \\
\hline
\end{tabular}


supported. All of these analyses were performed using PAST software (Hammer et al. 2001). We ran a Mantel test to correlate the matrix of distance in the composition (based on Jaccard) with a matrix of geographic distance. The last matrix was calculated based on the degrees of latitude and longitude (see Table 1) using Euclidean distance. The Mantel test was made in order to determine if spatial autocorrelation was present among the communities. This analysis was developed in the $\mathrm{R}$ program for statistical computing (R Core Team, 2014) with the vegan package (Oksanen et al. 2013).

\section{Results}

We recorded 779 individuals belonging to 21 small mammal species. Of these, 15 species were rodents and six were marsupials (Table 2). The species accumulation curve showed a tendency for stabilization (Figure 2).

The cluster analysis revealed two distinguished groups with a consistent similarity index (Figure 3). One group was comprised of the formations of southeastern and northeastern Brazil (SE/NE group), where all the locations are less than $80 \mathrm{~km}$ of the coast (CAF - Coastal Atlantic Forest) and had distinct forest features from each other. The second group included all of the studies in southern Brazil (SR group), and presents both interior forest formations (IAF - Interior Atlantic Forest, at least $180 \mathrm{~km}$ from the coast) and CAF formations. The composition of small mammal species in our study area was more similar to that found in the Erechim and Mato Castelhano municipalities (approximately 100 and $200 \mathrm{~km}$ from our study site, respectively). Erechim presents a forest formation very similar to ours, composed by a transition region between semideciduous and Araucaria forests (Budke et al. 2010). Mato Castelhano has a typical mixed ombrophilous forest dominated by Araucaria angustifolia (Bertol.) Kuntze (Araucaria forest) (Galiano et al. 2013). Regarding the others locations, IAF, Xanxerê and São Domingos have the same forest characteristics found in this study, a deciduous forest associated with elements from the Araucaria forest (Silva-Filho \& Pugues 2008, Netto et al. 2012), and Três Barras was originally composed by Araucaria forests, which currently are found only in small fragments (Cherem \& Perez 1996). Still, within the southern group the more extern studies in the cluster occurred in a strict Araucaria forest at Cambará do Sul (Dalmagro \& Vieira 2005) and in a Dense Submontane forest at

Table 2. Number of individuals captured and the frequency of occurrence of the 21 species recorded in the period of August 2011 (pilot field) and from October 2011 to September 2012 in Chapecó, Santa Catarina in southern Brazil. The equitability and dominance indices are displayed at the end of table. *This species is undergoing taxonomic revision and its epithet may be changed.

\begin{tabular}{|c|c|c|}
\hline Species & Number of individuals & Frequency of occurrence $(\%)$ \\
\hline \multicolumn{3}{|l|}{ Order Rodentia } \\
\hline \multicolumn{3}{|l|}{ Family Cricetidae } \\
\hline Oligoryzomys flavescens (Waterhouse, 1837) & 374 & 48.01 \\
\hline Akodon montensis Thomas, 1913 & 188 & 24.13 \\
\hline Sooretamys angouya (G. Fisher, 1814) & 49 & 6.29 \\
\hline Oligoryzomys nigripes (Olfers, 1818) & 40 & 5.13 \\
\hline Thaptomys nigrita (Lichtenstein, 1829) & 35 & 4.49 \\
\hline Abrawayaomys ruschii Cunha and Cruz, 1979 & 3 & 0.38 \\
\hline Brucepattersonius iheringi (Thomas, 1896) & 3 & 0.38 \\
\hline Juliomys pictipes* (Osgood, 1933) & 3 & 0.38 \\
\hline Necromys lasiurus (Lund, 1841) & 1 & 0.12 \\
\hline Nectomys squamipes (Brants, 1827) & 1 & 0.12 \\
\hline Oxymycterus judex Thomas, 1909 & 1 & 0.12 \\
\hline Euryoryzomys russatus (Wagner, 1848) & 1 & 0.12 \\
\hline \multicolumn{3}{|l|}{ Family Echimyidae } \\
\hline Euryzygomatomys spinosus (G. Fisher, 1814) & 2 & 0.25 \\
\hline \multicolumn{3}{|l|}{ Family Sciuridae } \\
\hline Guerlinguetus sp. & 1 & 0.12 \\
\hline \multicolumn{3}{|l|}{ Family Muridae } \\
\hline Mus musculus Linnaeus, 1758 & 9 & 1.15 \\
\hline \multicolumn{3}{|l|}{ Order Didelphimorphia } \\
\hline \multicolumn{3}{|l|}{ Family Didelphidae } \\
\hline Didelphis aurita (Wied-Neuwied, 1826) & 35 & 4.49 \\
\hline Monodelphis americana (Müller, 1776) & 13 & 1.66 \\
\hline Gracilinanus microtarsus (Wagner, 1842) & 10 & 1.28 \\
\hline Didelphis albiventris Lund, 1840 & 5 & 0.64 \\
\hline Monodelphis dimidiata (Hensel, 1872) & 5 & 0.64 \\
\hline Marmosa paraguayana (Tate, 1931) & 1 & 0.12 \\
\hline Richness & & 21 \\
\hline Individuals & & 779 \\
\hline Dominance & & 0.30 \\
\hline Equitability & & 0.55 \\
\hline
\end{tabular}




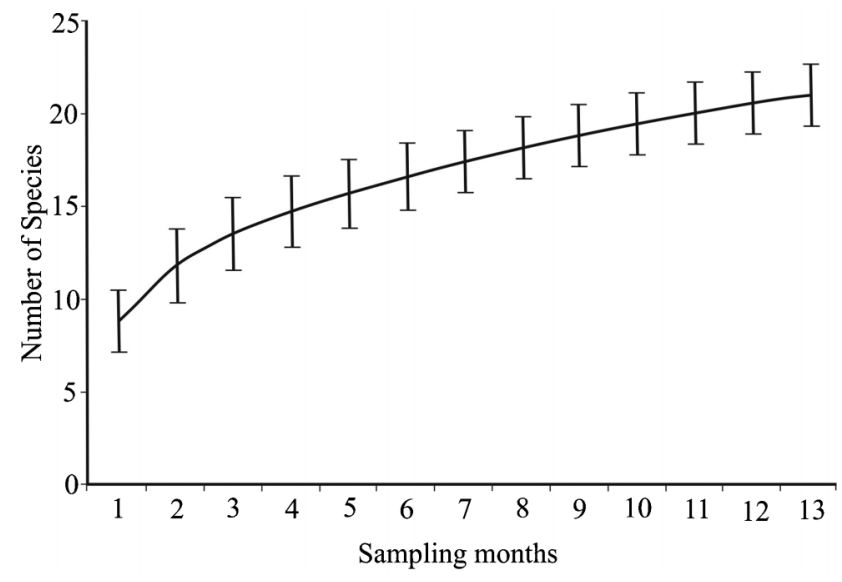

Figure 2. Species accumulation curve. Calculated based on data obtained in the period of August 2011 (pilot field) and from October 2011 to September 2012 in Chapecó, Santa Catarina in southern Brazil. The black line represents the mean, and the bars are the standard deviations generated by 1,000 randomizations. The numbers 1-13 correspond to the sampling months.

Florianópolis (Graipel et al. 2006). These last two localities are very close to the coastline. We found a geographically structured pattern of variation in species composition among the localities with the Mantel test $(\mathrm{r}=0.66 ; p=0.003)$; we observed that spatially closer populations are more similar in species composition, especially within the southern group, and more distant populations are more dissimilar (Figure 4).

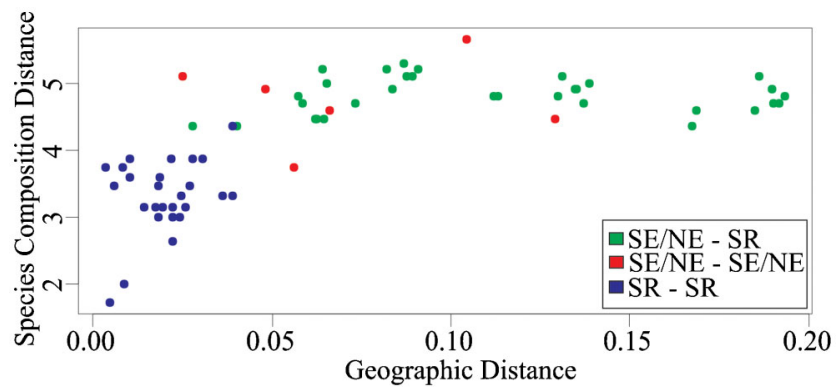

Figure 4. Scatterplot of the pairwise species composition distance against the pairwise geographic distance between localities. The species composition distance was calculated with Jaccard distance, and the geographic distance was calculated by Euclidean Distance. Mantel $r=0.66$. SR: Southern; SE/NE: Southeastern/Northeastern.

\section{Discussion}

The number of species found in this study $(n=21)$ is similar to other studies carried out in the Atlantic forest and approaches to. Pardini \& Umetsu (2006) reported one of the largest numbers of species in the biome $(n=23)$ in Cotia (São Paulo state) by a study using both pitfall traps as cages. Cotia is mostly covered by vegetation classified as dense mountain ombrophilous forest (Metzger et al. 2006). When compared to studies from the nearby areas of the deciduous and Araucaria forests, our results show a substantially greater number of species (Galiano et al. $2013 \mathrm{n}=6$, Kubiak et al. $2009 \mathrm{n}=7$; Cherem et al. $2012 n=20$, Cherem et al. $2008 n=12$, Dalmagro \& Vieira, $2005 \mathrm{n}=6$ ). This large number of species could be a

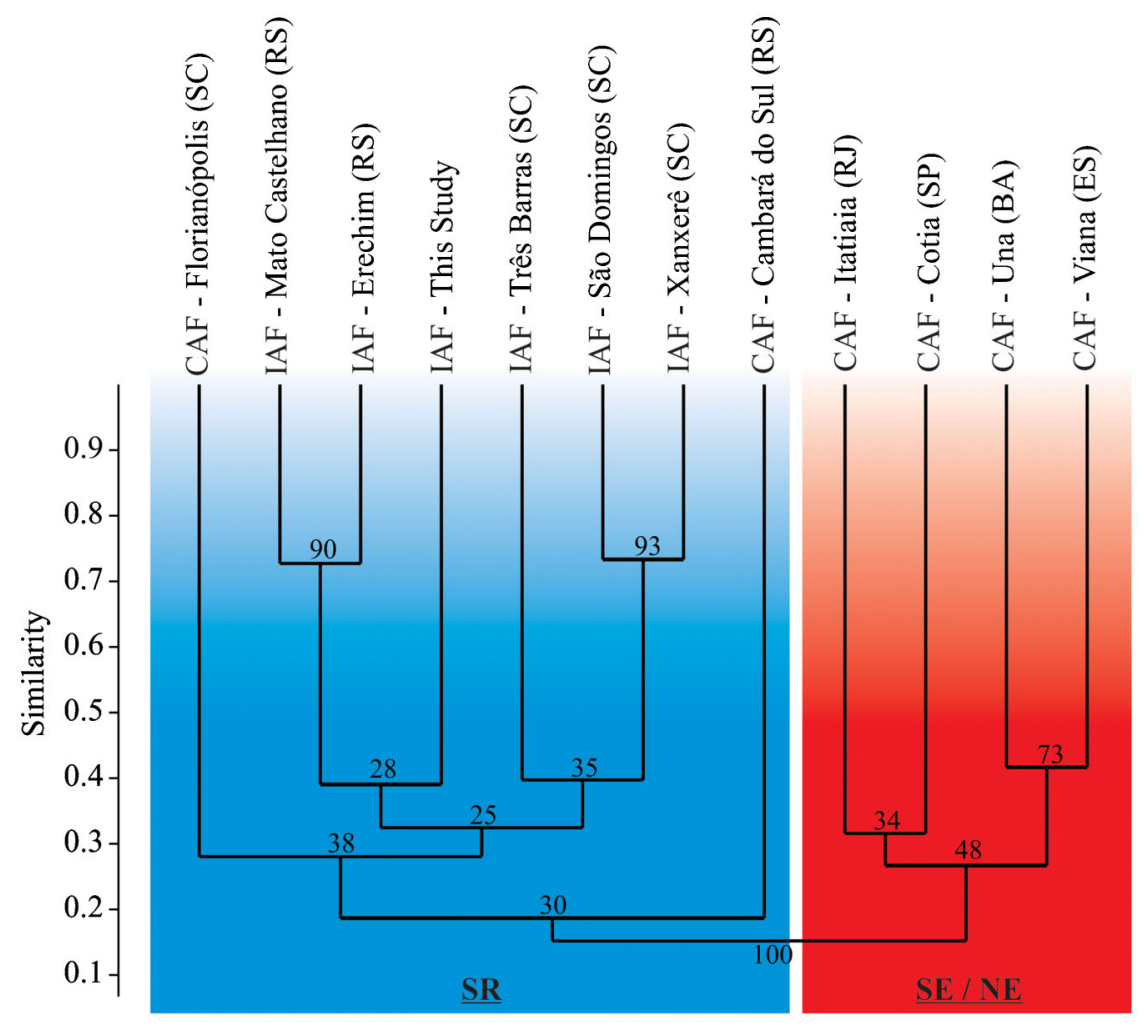

Figure 3. A cluster analysis showing the similarity in small mammal species composition among Atlantic forest localities. The tree was constructed based on Jaccard distance and a UPGMA algorithm. Numbers inside the tree represent the percentage of consistency of the similarity calculated by 1,000 bootstraps. SR: Southern; SE/NE: Southeastern/Northeastern. 
result of the conditions provided by the transition region between the both forest formations (as also found by Cherem et al. 2012 in the same forest characteristics). In addition, the high diversity we found is an indication that the interior forest formations may harbor a number of species comparable to those forests nearby the coast, and this might be a result of the presence of different physiognomies at the interior forests.

Despite the high richness found in the area, the fragment sampled is small compared to other sampled areas in the biome (Galiano et al. 2013, Pardini \& Umetsu 2006, Geise et al. 2004, Grelle 2003). In addition, the sample area is not protected under a conservation unit. Pardini \& Umetsu (2006) provided a summary of 20 surveys of small mammals in Atlantic Forest fragments representing an area greater than 700 ha; however, only two of these studies (Bonvicino et al. 1997 and Pardini \& Umetsu 2006) found richness equal to or greater than that reported here. In a study near the Paranapiacaba ecological continuum, Leiner \& Silva (2012) caught 20 species of small nonvolant mammals in one of the largest regions of Atlantic forest (due to the presence of four conservation units). In one of the few surveys conducted in the western region of the state of Santa Catarina, Cherem et al. (2012) recorded 20 species of small nonflying mammals; of these, three were exotic and 17 were native. This last study was also conducted in a non-protected area in a transition region between deciduous and Araucaria forest. Moreover, Cherem et al. (2012) used only cage traps, and their sampling effort was about 3,300 trap/nights, while our sampling effort was much bigger, totaling 6,500 trap/nights. It is important to denote that regions where high richness is associated with high anthropogenic threats, as in the present study, are clearly prioritized for biodiversity conservation, and protection efforts in such areas should be more urgent (Myers et al. 2000). The richness found in the area and the presence of rare and specialized species, such as Abrawayaomys ruschii and Juliomys pictipes are good indicators of the quality of this fragment in maintaining biodiversity.

The analysis of species composition revealed that forest formations in the Atlantic Forest biome in SR Brazil contain a unique set of species different from those found in SE/NE regions. This is most likely the result of geographic distance (Figure 4) and less clearly the result of the different types of physiognomies. All SE/NE areas are near to the coastline, while southern regions are composed by interior and coastal forests. Inside the southern region, there is one clearly closed cluster composed of interior forest formations that share similar species compositions. This group is composed of communities found in areas with characteristics of Deciduous, Semideciduous and Araucaria forests. The more dissimilar areas within the southern group are the two located near the coastline; one is a Dense Submontane forest (Graipel et al. 2006), and the other is an Araucaria forest (Dalmagro \& Vieira 2005). Therefore, the species composition found in our study is more influenced by the nearby communities and physiognomy characteristics of the Deciduous and Araucaria forests, than by distant regions.

Finally, the accumulation curve showed a tendency to stabilization. It is possible that species not yet registered would occur if sampling had continued. This fact, combined with all the data mentioned above, indicates the importance of this fragment in the maintenance of ecosystem diversity, and it is concerning that this area is not legally protected. It is important that more studies be conducted in nearby areas, and also in other interior Atlantic forest formations, in order to track the species diversity in other fragments, which will permit a more accurately assessment of the regional richness and species composition.

\section{Acknowledgements}

We thank Martin Maurer, Joana Boschetti and Elaine M. L. Gonsales for help in the field and AURORA Industry for authorization and support for our fieldwork. We thank Rodrigo Fornel, Thales R. O. de Freitas and Carlos Benhur Kasper for reading the manuscript and for valuable suggestions on an early version. We thank the Coordination for the Improvement of Higher Level Personnel (CAPES) for granting a scholarship to the first author and the National Counsel of Technological and Scientific Development (CNPq) for the scholarships granted to the second and third authors.

\section{References}

BEGON, M., TOWNSEND, C.R. \& HARPER, J.L. 2007. Ecologia: de indivíduos a ecossistemas. 4 ed. Porto Alegre, Artmed.

BONECKER, S.T., PORTUGAL, L.G., COSTA-NETO, S.F. \& GENTILE, R. 2009. A long term study of small mammal populations in a Brazilian agricultural landscape. Mammalian Biology, 74:467-477.

BONVICINO, C.R., LANGGUTH, A., LINDBERGH, S.M. \& PAULA, A.C. 1997. An elevational gradient study of small mammals at Caparaó National Park, Southeastern Brazil. Mammalia, 61:547-560.

BONVICINO, C.R., LINDBERGH, S.M. \& MAROJA, L.S. 2002. Small non-flying mammals from conserved and altered areas of Atlantic forest and cerrado: comments on their potential use for monitoring environment. Brazilian Journal of Biology, 62(4B):765774, http://dx.doi.org/10.1590/S1519-69842002000500005

BUDKE, J.C., ALBERTI, M.S., ZANARDI, C., BARATTO, C. \& ZANIN, E.M. Bamboo dieback and tree regeneration responses in a subtropical forest of South America. Forest Ecology and Management, 260:1345-1349, http://dx.doi.org/10.1016/j.foreco. 2010.07.028

CARVALHO, F.M.V., PINHEIRO, P.S., FERNANDEZ, A.S. \& NESSIMIAN, J.L. 1999. Diet of small mammals in Atlantic Forest fragments in southeastern Brazil. Revista Brasileira de Zoociências, 1:91-101.

CECHIN, S.Z. \& MARTINS, M. 2000. Eficiência de armadilhas de queda (pitfall traps) em amostragens de anfíbios e répteis no Brasil. Revista brasileira de zoologia, 17(3):729-740, http://dx.doi.org/ 10.1590/S0101-81752000000300017

CHEREM, J.J. \& PEREZ, D.M. 1996. Mamíferos terrestres de floresta de araucária no município de Três Barras, Santa Catarina, Brasil. Biotemas, 9(2):29-46.

CHEREM, J.J., ALTHOFF, S.L. \& REINICKE, R.C. 2008. Mamíferos. In A fauna das áreas de influência da Usina Hidrelétrica Quebra-Queixo (Cherem, J. J. \& Kammers, M. org). Habilis Editora, Erechim, Brasil, p.89-102.

CHEREM, J.J., ALTHOFF, S.L. \& TESTONI, A.F. 2012. Mamíferos. In Fisiografia, Flora e Fauna do Rio Irani. (Cherem, J.J. \& Samoria, V. org). ETS, Florianópolis, p. 137-159.

DALMAGRO, A.D., \& VIEIRA, E.M. 2005. Patterns of habitat utilization of small rodents in an area of Araucaria forest in Southern Brazil. Austral Ecology, 30:353-362, http://dx.doi.org/ 10.1111/j.1442-9993.2005.01447.x

FONSECA, G.A.B, HERMANN, G., LEITE, Y.L.R., MITTERMEIER, R.A., RYLANDS, A.B. \& PATTON, J.L. 1996. Lista anotada dos mamíferos do Brasil. Occasional Papers in Conservation Biology 4. Conservation Internacional, Belo Horizonte, Brazil. 
GALIANO, D. 2010. Dinâmica populacional e efeitos de variáveis ambientais sobre a fauna de pequenos mamíferos em um fragmento de floresta com araucária no sul do Brasil. Dissertação de Mestrado, Universidade Federal do Rio Grande do Sul, Porto Alegre, RS.

GALIANO, D., KUBIAK, B.B., MARINHO, J.R. \& FREITAS, T.R.O. 2013. Population dynamics of Akodon montensis and Oligoryzomys nigripes in an Araucaria forest of southern Brazil. Mammalia, 77(2):173-179, http://dx.doi.org/10.1515/mammalia2011-0128

GALINDO-LEAL, C.,CÂMARA, I.G. (Eds.) 2003. The Atlantic Forest of South America: Biodiversity status, Threats and Outlook. CABS and Island Press, Washington.

GEISE, L., PEREIRA, L.G., BOSSI, D.E.P. \& BERGALLO, H.G. 2004. Pattern of elevational distribution and richness of non volant mammals in Itatiaia National Park and its surroundings, in southeastern Brazil. Brazilian Journal of Biology, 64(3B):599-612, http://dx.doi.org/10.1590/S1519-69842004000400007

GRAIPEL, M.E., CHEREM, J.J., MONTEIRO-FILHO, E.L.A. \& GLOCK, L. 2006. Dinâmica populacional de marsupiais e roedores no parque municipal da lagoa do Peri, ilha de Santa Catarina, sul do Brasil. Mastozoologia Neotropical, 13(1):31-49.

GRELLE, C.E.V. 2003. Forest structure and vertical stratification of small mammals in a secondary Atlantic forest, southeastern, Brazil. Studies on Neotropical Fauna and Environment, 38:81-85, http:// dx.doi.org/10.1076/snfe.38.2.81.15926

HAMMER, O., HARPER, D.A.T. \& RYAN, P.D. 2001. PAST: Paleontological Statistics software package for education and data analysis. Paleontologica Eletronica, 4(11). 99p.

KUBIAK, B.B., ESTEVAN, C., GALIANO, D. \& MARINHO, J.R 2009. Comparação da fauna de pequenos mamíferos entre uma área de Floresta Estacional Semidecidual e reflorestamento de Pinus sp. Perspectiva (Erexim), 33:155-164.

KUBIAK, B.B. 2010. Efeito de borda sobre Akodon montensis Thomas, 1913, e Oligoryzomys flavescens Waterhouse, 1837 em um fragmento de floresta ombrófila mista. Trabalho de Conclusão de Curso, Universidade Regional do Alto Uruguai e das Missões, ErechimRS

LEINER, N.O. \& SILVA, W.R. 2012. Non-volant small mammals at an Atlantic forest area situated nearby a limestone quarry (Limeiraquarry), state of São Paulo, Brazil. Biota Neotrop. 12(4): $\mathrm{http} / / / \mathrm{www}$.biotaneotropica.org.br/v12n4/en/abstract?inventory+ bn02312042012 (ultimo acesso em: 15/10/2013)

METZGER, J.P., ALVES, L.F., GOULART, W., TEIXEIRA, A.M.G., SIMÕES, S.J.C. \& CATHARINO, E.L.M. 2006. Uma área de relevante interesse biológico, porém pouco conhecida: a Reserva Florestal do Morro Grande. Biota Neotrop. 6(2), http://www.biotaneotropica.org.br/v6n2/pt/abstract?article+ bn00206022006 (ultimo acesso em 11/08/2014).
MYERS, N., MITTERMEIER, R.A., MITTERMEIER, C.G., FONSECA, G.A.B. \& KENT, J. 2000. Biodiversity hotspots for conservation priorities. Nature, 403(6772):853 - 858, http:// dx.doi.org/10.1038/35002501

NETTO, R.S., SALMORIA, V. \& SANT'ANNA, F.S. 2012. Vegetação. In Fisiografia, Flora e Fauna do Rio Irani. (Cherem, J.J. \& Samoria, V. org). ETS, Florianópolis, p.28-32.

OKSANEN, J., BLANCHET, F.G., KINDT, R., LEGENDRE, P., MINCHIN, P.R., O'HARA, R.B., SIMPSON, G.L., SOLYMUS, P., STEVENS, M.H.H. \& WAGNER, H. 2013. Vegan: Community Ecology Package. R package version 2.0-7.

PAGLIA, A.P., FONSECA, G.A.B., RYLANDS, A.B., HERRMANN, G., AGUIAR, L.M.S., CHIARELLO, A.G., LEITE, Y.L.R., COSTA, L.P., SICILIANO, S., KIERULFF, M.C.M., MENDES, S.L., TAVARES, V.C., MITTERMEIER, R.A. \& PATTON, J.L. 2012. Annotated checklist of Brazilian mammals. 2 ed. Occasional Papers in Conservation Biology n.6, Conservation International, Arlington 76p.

PARDINI, R. \& UMETSU, F. 2006. Pequenos mamíferos nãovoadores da Reserva Florestal do Morro Grande - distribuição das espécies e da diversidade em uma área de Mata Atlântica. Biota Neotrop. 6(2) http://www.biotaneotropica.org.br/v6n2/pt/abstract?article+bn00606022006 (ultimo acesso em 15/10/2013), http:// dx.doi.org/10.1590/S1676-06032006000200007

PEEL, M.C., FINLAYSON, B.L. \& MCMAHON, T.A. 2007. Updated world map of the Köppen-Geiger climate classification. Hydrology and Earth System Sciences, 11:1633-1644, http:// dx.doi.org/10.5194/hess-11-1633-2007

PINTO, I.S., LOSS, A.C.C., FALQUETO, A. \& LEITE, Y.L.R. 2009. Pequenos mamíferos não voadores em fragmentos de Mata Atlântica e áreas agrícolas em Viana, Espírito Santo, Brasil. Biota Neotrop. 9(3):355-360 http://www.biotaneotropica.org.br/ v9n3/en/abstract?inventory+bn03109032009 (ultimo acesso em: 15/10/2013), http://dx.doi.org/10.1590/S1676-06032009000300030

PYARE, S. \& LONGLAND, W.S. 2001. Patterns of ectomycorrhizalfungi consumption by small mammals in remnant old-growth forests of the Sierra Nevada. Journal of Mammalogy, 82:681-689, http:// dx.doi.org/10.1644/1545-1542(2001)082<0681:POEFCB >2.0.CO;2

R Development Core Team. 2014. R: A language and environment for statistical computing. R Foundation for Statistical Computing, Vienna, Austria. ISBN 3-900051-07-0 .http://www.R-project.org/.

RIBEIRO-JÚNIOR, M.A., ROSSI, R.V., MIRANDA, C.L. \& ÁVILA-PIRES, T.C.S. 2011. Influence of pitfall trap size and design on herpetofauna and small mammal studies in a Neotropical forest. Zoologia, 28(1):80-91, http://dx.doi.org/10.1590/S198446702011000100012

SILVA-FILHO, F.A. \& PUGUES, S. 2008. Vegetação. In A fauna das áreas de influência da Usina Hidrelétrica Quebra-Queixo (Cherem, J.J. \& Kammers, M. org). Habilis Editora, ErechimBrasil, p.44-56. 